\title{
Evaluation of Chromium Composition of Commonly Consumed Leafy Vegetables Juice Selected from South West Nigeria
}

\author{
Kubura Temitope Odufuwa ${ }^{1}$, Moronke Muinat Adeyanju ${ }^{1}$, Charles Babatunde Adeosun ${ }^{2}$, \\ Adeleke Kazeem Atunnise ${ }^{1}$, Bamidele Adewale Salau ${ }^{2, *}$ \\ ${ }^{1}$ Department of Biochemistry, Faculty of Basic Medical Sciences, Obafemi Awolowo College of Health Sciences, Olabisi Onabanjo University, \\ Ogun State, Nigeria \\ ${ }^{2}$ Department of Chemical Sciences, College of Natural Sciences, Redeemer's University, Ede, Osun State, Nigeria
}

Email address:

delesalau@gmail.com (B. A. Salau)

To cite this article:

Kubura Temitope Odufuwa, Moronke Muinat Adeyanju, Charles Babatunde Adeosun, Adeleke Kazeem Atunnise, Bamidele Adewale Salau. Evaluation of Chromium Composition of Commonly Consumed Leafy Vegetables Juice Selected from South West Nigeria. Journal of Food and Nutrition Sciences. Vol. 3, No. 6, 2015, pp. 240-244. doi: 10.11648/j.jfns.20150306.17

\begin{abstract}
Chromium is necessary for insulin function, nutrient uptake and regulation of major metabolism as well as boosting of immune system amongst others; available in vegetables, the cheapest source for the majority of people living in developing countries. Seven commonly consumed vegetables in south west Nigeria were collected from four major markets in the region, thoroughly mixed and prepared for laboratory analysis. Each vegetables were shared into two groups (fresh and juice) and four replicates each, chromium content were determined using Atomic Absorbance Spectrophotometer. Highest chromium content was observed in Senecio biafrae $(4.73 \pm 0.05)$ and it is significantly $(\mathrm{p}<0.05)$ higher than other experimented samples while, the least was observed in Piper guineense $(0.89 \pm 0.30)$ and is significantly $(\mathrm{p}<0.05)$ lower than other fresh leafy vegetables. Among the juice extracts Senecio biafrae $(29.80 \pm 2.11)$ contain the highest chromium content and significant difference ( $\mathrm{p}>0.05)$ while, Corchorus oliterus $(10.90 \pm 0.50)$ is significantly $(\mathrm{p}<0.05)$ lower than other vegetables. Comparatively, chromium content in juice extracts are significantly higher than their corresponding fresh vegetables. Therefore caution most be applied when juice of vegetables are to be ingested especially in Piper guineense which displayed a significantly increase chromium content when juiced.
\end{abstract}

Keywords: Processing, Chromium, Vegetables, Juice, Toxicity

\section{Introduction}

Chromium a trace element in trivalent chromium state is essential metal utilized in the human body for glucose conversion by insulin-driven reactions in carbohydrate metabolic pathways [1]. An antidepressant which helps in prevention of obesity and type 2 diabetes mellitus by preventing appetite in insulin resistance and glucose intolerance as well as regulation of body composition[2, 3]. While chromium intake is crucial in optimal energy metabolism and regulation excess consumption has been reported to accumulate intracellular $\mathrm{Cr} 3+$ ions that may lead to long-term genotoxic effects by formation of covalent bonds to DNA [4]. Taken together, cytotoxic, genotoxic and mutagenic effects as well as activity damaging to the mitochondria and induction of apoptosis have been reported for $\mathrm{CrPic}$ using mammalian cell cultures [5, 6]. Animal studies showed that administration of chromium to pregnant mice resulted in skeletal birth defects in the developing fetus [7]. Chromium toxicity has been reported to induce oxidative stress which may result in renal impairment [8]; severe biochemical, histological and morphological changes in the eye; skin blisters and pustules; anaemia; hemolysis; tissue oedema; liver dysfunction; neuronal cell injury; impaired cognitive, perceptual and motor activity[7, 9]; enhanced production of hydroxyl radicals; chromosomal aberration and depletion of antioxidant enzymes. Hence, case reports have described acute kidney failure, liver damage and anaemia by taking high dosage of $\mathrm{CrPic}$ as a dietary supplement $[8,9]$. Chromium is naturally available in food sources such as meat, fish, grains, brewer's yeast, fruits and 
vegetables [10].

Vegetables constitute the cheapest source of essential trace element for the majority of people living in developing countries which is processed into various form before consumption [11, 12], food processing, being one of the earliest technologies that man has been using, has the advantage of insuring food supply and in many cases as a necessary step before consumption for a variety of reason, such as increasing stability and bioavailability, improving flavour, decreasing possibility of toxicity and introducing functioning ability. [12, 13]. However, this processing sometimes introduces factors that may affect nutritional values adversely [12].

In the past consumption of fresh (unprocessed) vegetable was uncommon, but of recent the use of vegetable juice such as Telfairia occidentalis (probably for hemopoetic value) and Vernonia amygdalina (probably for antidiabetic and other therapeutic purpose) is on increase among Nigerian populace[14]. While the juicing is believed to concentrate the nutrients, thus, the chromium content which may also be concentrated possibly to the level that might affect the consumer adversely $[12,14]$. In view of the above, we set to investigate the content of chromiumin fresh vegetables and how its level is affected by juicing.

\section{Materials and Methods}

\subsection{Sample Collection}

Vegetables used for the study were purchased from four major markets; Ago-iwoye, Ikenne and sagamu markets in Ogun state and Ketu market in Lagos state, Nigeria. The weight of the samples varied from $1-5 \mathrm{~kg}$. The samples were identified at the herbarium of the plant science and zoology department, Olabisi Onabanjo University.

\subsection{Sample Preparation}

The vegetables purchased were prepared by removing the leaves from the edible part of the vegetables. The prepared samples were thoroughly mixed together specimen and divided into four parts.

\subsection{Juicing}

This was carried out by using master chef juice extractor (model no: mc-J2101). The juice and pulp were collected separately.

\subsection{Sample Analysis}

Moisture content: The moisture content was determined by ISO (1973) [15] methods. In which about $10 \mathrm{~g}$ of each sample from each replicate into a $200 \mathrm{ml}$ crucible and then it was dried in oven at a temperature of $105^{\circ} \mathrm{C}$ for 24hours.

Chromium content: The chromium content was analyzedby Parkhurst (1998) [16] methods. 10g of each sample was added into a conical flask and heated on a hot plate at $200^{\circ} \mathrm{C}$, for 45 minutes, then in a furnace at $500^{\circ} \mathrm{C}$ until the weight was drastically reduced to near dryness. Then digested by adding $10 \mathrm{~mL}$ conc. aqua regia $(3: 1 \mathrm{HCl}: \mathrm{HNO} 3)$ and heated to dryness. Twenty $\mathrm{ml}$ de-ionized water was added, stirred and filtered. The filtrate was made up in standard volumetric flask. Chromium was assayed with a AA 7000 Atomic Absorption Spectrophotometer with detection limit of 0.001 . The background level found in a blank container was $0.001 \mathrm{mg} / \mathrm{L}$. The true intake using the arithmetic mean according to [15] was calculated by multiplying contaminant level (heavy metal level by amount/ volume of sample. In all the calculated levels of chromium in the sample, $5 \mathrm{~mL}$ was assumed to be the average volume for the sample.

\subsection{Statistical Analysis}

The experimental design was completely randomized. Data were analyzed using the Statistical Package for Social Sciences (SPSS) 16. Significant difference between the data was determined at $\mathrm{p}<0.05$ using Duncan multiple range test.

\section{Results}

Table 1. Chromium and Moisture Content of Some Selected Fresh Vegetables.

\begin{tabular}{llll}
\hline Botanical Name & Local/CommonName & Chromium Content (mg/ 100g dry weight) & Percentage Moisture Content (\%) \\
\hline Piper guineense & West African black pepper / Uziza & $0.89 \pm 0.30^{\mathrm{a}}$ & $85.87 \pm 0.36^{\mathrm{b}, \mathrm{c}}$ \\
Ipomoea batatas & Sweet potatoes leaf / Ewe odukun & $2.10 \pm 0.08^{\mathrm{b}}$ & $86.37 \pm 0.06^{\mathrm{b}, \mathrm{c}}$ \\
Amaranthus spp. & Joy weed/ Ebiden & $2.31 \pm 0.05^{\mathrm{b}}$ & $85.20 \pm 0.41^{\mathrm{b}}$ \\
Corchorus oliterus & Long-fruited vegetable / Ewedu & $2.95 \pm 0.08^{\mathrm{c}}$ & $82.10 \pm 0.33^{\mathrm{a}}$ \\
Manihot esculenta & Cassava leaf / Ewe paki & $3.22 \pm 0.30^{\mathrm{c}}$ & $85.08 \pm 1.33^{\mathrm{b}}$ \\
Launea taraxacifolia & Wild lettuce / Yanrin & $3.91 \pm 0.05^{\mathrm{d}}$ & $86.90 \pm 0.15^{\mathrm{c}}$ \\
Senecio biafrae & Oliv. and Hiern / Woorowo & $4.73 \pm 0.05^{\mathrm{e}}$ & $87.23 \pm 0.22^{\mathrm{c}}$ \\
\hline
\end{tabular}

Values are mean \pm SEM of 4 determinations, Values in the same column with different superscripts are significantly different from each other ( $<<0.05$ ). 
Table 2. Chromium and Moisture Content of Some Selected Vegetables Juice.

\begin{tabular}{llll}
\hline Botanical Name & Local/CommonName & Chromium Content (mg/ 100g dry weight) & Percentage Moisture Content (\%) \\
\hline Piper guineense & West African black pepper/ Uziza & $19.44 \pm 0.88^{\mathrm{c}}$ & $95.62 \pm 0.2^{\mathrm{b}, \mathrm{c}}$ \\
Ipomoea batatas & Sweet potatoes leaf / Ewe odukun & $15.63 \pm 0.13^{\mathrm{b}}$ & $94.87 \pm 0.06^{\mathrm{b}}$ \\
Amaranthus spp. & Joy weed/ Ebiden & $17.80 \pm 1.79^{\mathrm{b}, \mathrm{c}}$ & $95.20 \pm 0.46^{\mathrm{b}, \mathrm{c}}$ \\
Corchorus oliterus & Long-fruited vegetable/ Ewedu & $10.90 \pm 0.50^{\mathrm{a}}$ & $92.13 \pm 0.36^{\mathrm{a}}$ \\
Manihot esculenta & Cassava leaf/ Ewe paki & $21.80 \pm 0.32^{\mathrm{c}}$ & $95.03 \pm 1.36^{\mathrm{a}, \mathrm{b}}$ \\
Launea taraxacifolia & Wild lettuce/ Yanrin & $28.40 \pm 0.99^{\mathrm{d}}$ & $97.08 \pm 0.9^{\mathrm{b}, \mathrm{c}}$ \\
Senecio biafrae & Oliv. and Hiern / Woorowo & $29.80 \pm 2.11^{\mathrm{d}}$ & $97.13 \pm 0.17^{\mathrm{c}}$ \\
\hline
\end{tabular}

Values are mean \pm SEM of 4 determinations, Values in the same column with different superscripts are significantly different from each other ( $<0.05$ ).

Table 3. Percentage change in chromium and moisture Content of Some Selected Vegetables.

\begin{tabular}{llll}
\hline Botanical Name & Local/CommonName & Chromium Content (\%) & Percentage Moisture Content (\%) \\
\hline Piper guineense & West African black pepper / Uziza & 2084.27 & 11.35 \\
Ipomoea batatas & Sweet potatoes leaf / Ewe odukun & 644.29 & 9.84 \\
Amaranthus spp. & Joy weed/ Ebiden & 670.56 & 11.74 \\
Corchorus oliterus & Long-fruited vegetable / Ewedu & 269.49 & 12.22 \\
Manihot esculenta & Cassava leaf / Ewe paki & 577.02 & 11.69 \\
Launea taraxacifolia & Wild lettuce / Yanrin & 626.34 & 11.71 \\
Senecio biafrae & Oliv. and Hiern / Woorowo & 530.02 & 11.35 \\
\hline
\end{tabular}

Values are mean \pm SEM of 4 determinations, Values in the same column with different superscripts are significantly different from each other $(\mathrm{p}<0.05$ ).

Table 1 above showed fresh vegetables and the variation in chromium content in fresh leafy vegetables. Highest chromium content was observed in Senecio biafrae $(4.73 \pm 0.05)$ and it is significantly $(p<0.05)$ higher than other experimented samples. No significant difference $(\mathrm{p}>0.05)$ was observed between Corchorus oliterus (2.95 \pm 0.08$)$ and Manihot esculenta (3.22 \pm 0.30$)$ as well as Ipomoea batatas (2.10 \pm 0.08$)$ and Amaranthus spp. $(2.31 \pm 0.05)$ while the least chromium content was recorded in Piper guineense $(0.89 \pm 0.30)$ and it significantly $(\mathrm{p}<0.05)$ lower than other vegetables.

Table 2 revealed chromium content in juice extracts of green leafy vegetables. Senecio biafrae (29.80 \pm 2.11$)$ contains the highest, with significant difference $(\mathrm{p}>0.05)$ when compared with Launea taraxacifolia (28.40 \pm 0.99$)$, however no significant difference $(\mathrm{p}>0.05)$ was observed between Manihot esculenta (21.80 \pm 0.32 ), Piper guineense

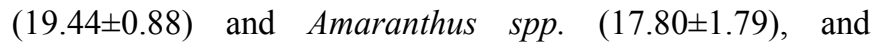
Ipomoea batatas (15.63 \pm 0.13$)$ and Piper guineense while, Corchorus oliterus $(10.90 \pm 0.50)$ is significantly $(\mathrm{p}<0.05)$ lower than other vegetables.

Table 3 displayed percentage change in chromium content after juicing fresh leafy vegetable. The highest increase was observed in Piper guineense with over 20 folds increase (2084.27), about six to seven folds increase was observed in Senecio biafrae, Manihot esculenta, Launea taraxacifolia, Ipomoea batatas, Amaranthus spp., the least percentage increase was noted in Corchorus oliterus about two and half folds increase $(269.49 \%)$.

\section{Discussion}

Chromium contents in plants especially vegetable crops is dependent on wide range of factors such as environmental, water and soil contamination with heavy metals, tissue distributions of divers essential elements and genetic factors. Juicing increased chromium content in all the leafy vegetables experimented. The high chromium content recorded in Senecio biafrae could be attributed to elevated level of chromium present in the soil via fertilizers and other organic matter application for soil improvement $[17,18]$; decline in soil $\mathrm{pH}$ to 3.3 which may rapidly increase the solubility and availability of chromium in soil [19].

In addition, the interactions of soil-plant roots-microbes play important roles in regulating heavy metal movement from soil to the edible parts of crops. Also, agronomic practices such as fertilizer and water management and crop rotation system can affect bioavailability and crop accumulation of heavy metals, thus influencing the amount of heavy metals in food chain [20].Thus, the various environmental conditions and agronomic practices may affect the accumulation of chromium in addition to inherent ability of individual plants to accumulate particular elements differently $[12,21]$.

Various storage and detoxification strategies, such as metal chelation, transport, sequestration into the vacuole as well as activation and synthesis of stress-related proteins and signaling molecules utilized by other parts of plants including 
leaf may be responsible for the high chromium content recorded in Corchorus oliterus, Manihot esculenta, Launea taraxacifolia and Senecio biafrae [22].

Juicing, a mechanical means of extracting plants tissue component requires the addition of water especially for leafy vegetables. The water used in this process may cause reduction, oxidation, sorption, desorption, dissolution, and precipitation [23] of chromium, which are usually in bound state with carbohydrates especially those with high cellulose content [24]. Also, in the process of extraction the $\mathrm{pH}$ of the juice extract is altered thereby increasing the solubility of $\mathrm{Cr}$ (III) ion present in the plants tissue in turn increases chromium content in vegetable juice extract, as observed in all the vegetables studied. Under neutral to basic $\mathrm{pH}, \mathrm{Cr}$ (III) will precipitate and conversely under acidic $\mathrm{pH}$ it will tend to solubilize [23, 24], thus, both bound and free chromium precipitate in the juice extract.

Piper guineense with over 20 folds increase (2084.27), about six to seven folds increase was observed in Senecio biafrae, Manihot esculenta, Launea taraxacifolia, Ipomoea batatas, Amaranthus spp., the while least percentage increase was noted in Corchorus oliterus (269.49\%). This study revealed that juicing significantly increases chromium content in all the leafy vegetables studied.

From the ongoing it is therefore expedient that caution must be exercised in taking the juice of the vegetable with high level of chromium because of the aforementioned adverse effect of chromium toxicity.

\section{Conclusion}

This work revealed the effect of juicing on chromium contents in green leafy vegetables. In this context, accumulation of chromium in edible plants and their juice extracts may represent a potential hazard to animals and humans especially in infants and pregnant women, also chromium competition with iron uptake and bioavailability may be a devastating complication in subjects susceptible to iron deficiency.

\section{Acknowledgement}

We acknowledge college of Natural sciences, Redeemers University for granting the laboratory space for this work, also special thanks to Professor G. A. Kolawole the former Head of Department of chemical sciences for his moral support.

\section{References}

[1] Walter H. Glinsmanna and Walter Mertz (1996).Effect of trivalent chromium on glucose tolerance. Metabolism; 15(6): $510-520$.

[2] Rex O. Brown Pharm D, Sue Forloines-Lynn RN, Robert E. Cross PhD, MD, William D. Heizer MD (1986).Chromium deficiency after long-term total parenteral nutrition. Digestive Diseases and Sciences; 31(6) 661-664.
[3] Richard A Anderson, Nanzheng Cheng, Noella A Bryden, Marilyn M Polansky, Nanping Cheng, Jiaming Chi and Jinguang Feng(1997). Elevated Intakes of Supplemental Chromium Improve Glucose and Insulin Variables in Individuals With Type 2 Diabetes. Diabetes; 46(11): 1786-1791.

[4] W Qi, R J Reiter, D X Tan, J J Garcia, L C Manchester, M Karbownik, and J R Calvo (2000). Chromium (III)-induced 8-hydroxydeoxyguanosine in DNA and its reduction by antioxidants: comparative effects of melatonin, ascorbate, and vitamin E. Environ Health Perspect.; 108(5): 399-402.

[5] Kuppusamy Balamurugan, Rama Rajaram, Thirumalachari Ramasami and Sujatha Narayanan (2002).Chromium(III)-induced apoptosis of lymphocytes: death decision by ROS and Src-family tyrosine kinases. Free Radical Biology and Medicine; 33(12): 1622-1640.

[6] Marisa D Pulido and Alan R Parrish (2003). Metal-induced apoptosis: mechanisms. Mutation Research/Fundamental and Molecular Mechanisms of Mutagenesis; 533(1-2): 227-241

[7] M.M. Bailey, J.G. Boohaker, R.D. Sawyer, J.E. Behling, J.F. Rasco, J.J. Jernigan, R.D. Hood, and J.B. Vincent (2006). Exposure of pregnant mice to chromium picolinate results in skeletal defects in their offspring. Developmental and Reproductive Toxicology; 77(3): 244-249

[8] Ellis E.N., Brouhard B.H., Lynch R.E., Dawson E.B., Tisdell R., Nichols M.M., Ramirez F. (1982): Effects of hemodialysis and dimercaprol in acute dichromate poisoning. Journal of Toxicology Clinical Toxicology, 19, 249-258.

[9] Lee C.R., Yoo C.I., Lee J.H., Kang S.K. (2002): Nasal septum perforation of welders. Industrial Health, 40, 286-289.

[10] William T. Cefalu and Frank B. Hu (2004).Role of Chromium in Human Health and in Diabetes. Diabetes Care; 27(11): 2741-2751.

[11] Oyenuga, V.A. and B.L. Fetuga, (1975). First National Seminar on Fruits and vegetables, In process and Recombination by NIHORT, Ibadan, Nigeria, 13-17: 122-123.

[12] Odufuwa Kuburat Temitope, Atunnise Adeleke, Kinnah Hudson joseph, Adeniji, P. O and Salau Bamidele Adewale (2013).Changes in Saponins Content of Some Selected Nigerian Vegetables during Blanching and Juicing. Journal Of Environmental Science, Toxicology And Food Technology; 3(3): $38-42$.

[13] Salau, B. A, Ajani E .O, Odufuwa, K. T., Adegbesan, B. O, and Soladoye, M. O (2010). Effect of processing on iodine content of some selected plants food. African Journal of Biotechnology Vol. 9(8): 1200-1204.

[14] Odufuwa, Kuburat Temitope, G. G. Daramola, P. O. Adeniji, Bamidele Adewale Salau. Changes in Alkaoids Content of Some Selected Nigerian Vegetables during Processing. Journal of Dental and Medical Sciences; 6(1): 51-54.

[15] ISO (1973). Determination of Moisture Content, ISO 1442 1973. International Organization for Standardization, Geneva, Switzerland.

[16] Parkhurst, D.F. Arithmetic versus geometric means for environmental concentration data. Environ. Sci. Technol. 1998, $32,92 \mathrm{~A}-98 \mathrm{~A}$. 
[17] Ghosh, U. C., Dasgupta, M., Debnath, S., and Bhat, S. C. (2003).Studies on management of chromium (VI)-contaminated industrial waste effluent using hydrous titanium oxide (HTO). Water, Air, and Soil Pollution, 143, $245-256$.

[18] Shams, K. M., Tichy, G., Fischer, A., Sager, M., Peer, T., Bashar, A., et al. (2010). Aspects of phytoremediation for chromium contaminated sites using common plants Urticadioica, Brassica napus and Zea mays. Plant and Soil, 328, 175-198.

[19] Chuan, M. C., Shu, G. Y., and Liu, J. C. (1996). Solubility of heavy metals in a contaminated soil: effects of redox potential and $\mathrm{pH}$. Water, Air, and Soil Pollution, 90(3-4), 543-556.

[20] Ejazul Islam, Xiao-e Yang, Zhen-li He, and Qaisar Mahmood (2007).Assessing potential dietary toxicity of heavy metals in selected vegetables and food crops. J Zhejiang Univ Sci B. J; 8(1): 1-13.
[21] Mirosław Wyszkowski and Maja Radziemska (2013). Assessment of Tri- and Hexavalent Chromium Phytotoxicity on Oats (Avenasativa L.) Biomass and Content of Nitrogen Compounds Water Air Soil Pollut; 224:1619.

[22] Rong Wang, Fei Gao, Bing-Qian Guo, Ji-Chang Huang, Lei Wang, and Yi-Jun Zhou (2013). Short-Term Chromium-Stress-Induced Alterations in the Maize Leaf Proteome. Int J MolSci; 14(6): 11125-11144.

[23] Geoffrey J. Puzon, Arthur G. Roberts, David M. Kramer, and Luying Xun (2005). Formation of Soluble Organo-Chromium(III) Complexes after Chromate Reduction in the Presence of Cellular Organics. Environ. Sci. Technol; 39 (8) 2811-2817.

[24] Ismael Acosta R., chitl Rodriguez, Conrado Gutirrez and Ma.de Guadalupe Moctezuma (2004). Biosorption of Chromium (VI) from Aqueous Solutions onto Fungal Biomass. Bioorganic Chemistry and Applications; 2: 1-2. 